\title{
EU Fiscal Governance Reforms: A Perspective of Independent Fiscal Institutions
}

Designing an EU fiscal governance framework that ensures long-run fiscal sustainability, while pursuing appropriate counter-cyclical policies and contributing to sustainable growth, social and climate objectives, is a challenging task. Fiscal policy is multi-dimensional, complicated and uncertain. Political pressures often lead to short-termism and excessive risk-taking. In addition, the EU and euro area frameworks need to work for very different economies and manage the risk of spillovers.

The shortcomings of the existing framework in terms of weak compliance, procyclicality and excessive complexity are well known. Many proposals to reform EU fiscal governance have looked to strengthening the role of national independent fiscal institutions (IFIs).

This contribution draws on a recent analysis prepared through the EU Network of Independent Fiscal Institutions (EUIFI, 2021) to offer a perspective of national independent fiscal institutions. IFIs in the EU member states are independent official bodies with mandates to oversee different aspects of fiscal policy, including forecasting, compliance with fiscal rules and assessing various aspects of the fiscal position. While some EU IFIs are long-standing institutions, many were created in their existing roles by the EU governance reforms of the early 2010 s.

National IFIs have a unique perspective and experience on EU fiscal governance, both in terms of the role that IFIs could play and on fiscal policy more widely. IFls bring a practical perspective on the realities of national fiscal policies and how fiscal frameworks work in practice.

This paper sets out a three-pillar approach to strengthening the EU fiscal framework based on: improving the numerical fiscal rules, strengthening the role of national IFIs and ameliorating statistics and data on the public finances.

(C) The Author(s) 2022. Open Access: This article is distributed under the terms of the Creative Commons Attribution 4.0 International License (https://creativecommons.org/licenses/by/4.0/).

Open Access funding provided by ZBW - Leibniz Information Centre for Economics.

Sebastian Barnes, Network of EU Independent Fiscal Institutions, Brussels, Belgium; Irish Fiscal Advisory Council, Dublin, Ireland.

\section{A three-pillar architecture}

The fiscal framework needs in practice to achieve a balance between, on the one hand, effective budgetary rules that allow governments to commit to sound policies and, on the other, judgements and discretion in how these are applied so that the framework adequately reflects the complexity of the situations that countries may find themselves in. Alternative approaches to setting fiscal rules may require more or less judgement or discretion, but no simple set of rules alone is likely to be able to deliver the required outcomes across all states of the world, taking into account national specificities.

A three-pillar architecture would support effective EU fiscal governance by providing (Figure 1) continued reliance on simpler numerical fiscal rules, an enhanced role for IFI analyses and assessments in the context of the EU surveillance cycle, and improved information on budgetaryrelevant metrics.

The three pillars are mutually reinforcing. Numerical rules can provide a transparent benchmark and objective basis for setting and assessing policy. They allow politicians to commit to long-run budgetary goals. However, rules require monitoring and interpretation. The Commission and the Council currently play this role at the EU level. An enhanced role of the national IFIs as independent expert bodies could help on specific issues in the application of the rules to national circumstances, such as the assessment of discretionary revenue measures and improving budgetary forecasts, and provide assessments of fiscal sustainability. Adequate data and information is needed both to implement rules effectively and to support oversight of budgetary policy.

Relying on rules alone is likely to be unduly blunt. Simple rules would risk being either too strict to enforce or too lenient, while richer frameworks quickly become highly complex without necessarily resolving all issues that may arise. For example, structural balance-based approaches aim to get closer to a full economic assessment than using headline measures but open up a complicated set of problems around the measurement of the output gap. Conversely, relying entirely on policy discretion or on IFIs' assessments, for example, without any numerical framework that sets high-level policy objectives or that provides benchmarks against which policy can be compared, is 
Figure 1

Three-pillar architecture to strengthen the EU fiscal framework

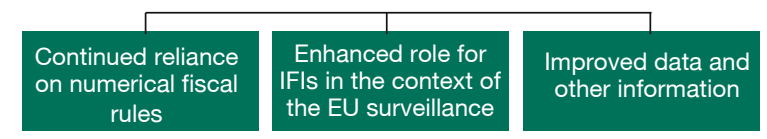

Note: IFIs stands for national independent fiscal institutions.

Source: Author's own compilation.

unlikely to result in a robust fiscal framework. While some have proposed moving away from rules altogether (Blanchard et al., 2021), such an approach is likely to face a number of practical changes, including the difficulty of making standards binding in many EU political systems.

Improving the numerical rules

While fiscal rules should remain at the heart of the EU framework, the numerical rules need to be better designed to improve compliance, reduce risks of procyclicality and be simpler. There are a number of ways this could be achieved and many different proposals have been made, each with different advantages and disadvantages.

However, what may matter more than high-level design choices is that any set of rules is well designed. The EUIFI (2021) paper sets out four main criteria for the new set of fiscal rules:

- simplicity

- transparency

- reduced procylicality

- a multi-annual focus.

In terms of how fiscal policy is managed, the most critical of these for achieving fiscal sustainabilitly is arguably moving towards a genuinely medium-term framework rather than one focussed on achieving fiscal goals one year at a time, which risks both policy drifting over time and being too inflexible in the near term.

Most reform proposals focus on two approaches to overhauling the rules. The first approach is the "debt anchor, expenditure ceiling" concept that aims to bring debt levels below a certain threshold deemed sustainable (debt anchor) by using a single operational rule (expenditure ceiling) as a lever. This approach has been advocated by the European Fiscal Board (EFB, 2020) and others (including Bénassy-Quéré et al., 2018; Constancio, 2020; Martin et al., 2021). Most proposals retain the current $60 \%$ public debt reference value over some horizon while others set the debt anchor through a formula or politically.

The second approach is to modify the existing EU Stability and Growth Pact framework with some simplification in the number of rules and their application (Feld et al., 2020). This could be achieved by focussing more on the existing expenditure benchmark, continuing the trend in recent years towards growing emphasis on this measure. The expenditure benchmark sets a ceiling for allowable expenditure growth (adjusted for discretionary revenue measures) based on the ten-year average growth of potential output and a convergence term intended to progress towards the medium-term objective for the structural balance, which itself partly depends on the deviation of debt from the $60 \%$ ceiling. While still reliant on measures of potential output, the expenditure path is less sensitive to measurement error along the path of potential output. Furthermore, the benchmark does not rely on estimates of the cyclical elasticity of tax revenues and so comes closer to tracking a bottom-up measure of the structural balance based on spending growth and tax policy changes than the standard approach of removing cyclical components from the headline balance.

In theory, the two proposed approaches can be viewed as achieving a similar outcome for the public finances. Both could be used to set a multiannual expenditure target, whether anchored directly in a debt objective or through the structural balance. In practice, however, there may be advantages and disadvantages to how each performs. This will depend critically on specific design features of their implementation.

The use of an expenditure ceiling as operational tool is attractive because government expenditures are mostly under the direct control of governments, largely independent of the business cycle, and have smaller forecast errors (Feld et al., 2018) than structural balances. A welldesigned multi-year expenditure ceiling should avoid the risk of increasing spending in a procyclical way during good times. It would strongly support domestic mediumterm budgetary frameworks.

A key design challenge is to ensure that the expenditure ceiling sets a stable path for the medium-term spending. The current EU expenditure benchmark does not do this: It is prone to revision, even with ten-year averaging, because of its reliance on a volatile measure of potential output (Barnes and Casey, 2019). Furthermore, the expenditure benchmark spending level depends on spending in the previous year, including locking in small overruns that raise the base or underspends that limit future spending. Setting the expenditure ceiling based on a level of spend- 
ing of multiple years would be a significant step towards a more long-term and stability-oriented fiscal policy. The expenditure ceiling or benchmark needs to be predictable yet flexible enough to allow some adjustment if the economy follows a very different path from what was originally planned. This could imply fixing the nominal expenditure ceiling several years at a time, for example for at least three years. As discussed below, appropriate estimates for the medium-term growth path of the economy are a necessary underpinning for this approach.

Several other design issues around numerical EU fiscal rules also need to be addressed (EUIFI, 2021). First, the treatment of deviations from spending rules in specific circumstances could be addressed, including through an adjustment margin for overruns and a rainy-day fund for governments that want to build up more savings in good times to manage any future downturns. Second, growthenhancing government investment may warrant special treatment and recognition in the design of the rules. Darvas and Wolff (2021) make a similar proposal with respect to "green" investment. Across all these areas, the advantages and drawbacks of these provisions need to be carefully weighed to ensure that they enhance the fiscal framework rather than undermine it.

Any proposal to reform the rules should be carefully tested and evaluated rather than just relying on a priori reasoning (Barnes and Oliinyk, 2021). This has been a weakness in the implementation of past reforms, as well as in some current proposals. Most strikingly, the one-twentieth debt reduction target has proven very difficult to apply at face value for high debt countries because it frontloads debt reduction and can imply an excessive fiscal tightening. This problematic issue would have been apparent had the rule been properly tested at the time. There are many other examples of such issues, such as the procyclicality of the structural balance requirements in real time for some countries (Barnes and Casey, 2019). Ideally, the rules should be tested against a wide range of possible outcomes, starting with medium-term forecasts for each country's public finances. The testing should examine the pseudo-real time performance of the model, the risks and the opportunities for countries to game the rules.

\section{Strengthening the role of IFIs}

The capacity of national IFIs to make independent objective assessments of national fiscal dynamics and to increase transparency could be used more effectively in the EU fiscal framework. IFIs can help to produce more accurate and less biased fiscal forecasts (Beetsma et al., 2018). By improving monitoring and transparency, IFIs improve compliance with fiscal rules (Lledo, 2018). IFIs can help to make the case for sound fiscal policies (Beetsma et al., 2017) and to contribute to deficit reduction (Capraru et al., 2020). As increasingly noted, IFls have a strong ability to engage with the public through national media (European Commission, 2021) and with domestic institutions such as national parliaments. This can help to anchor compliance with the fiscal framework in the national political landscape.

In terms of the EU fiscal governance, the capacity of IFIs is currently limited to a number of specific areas. First, IFIs monitor compliance with domestic fiscal rules that mirror EU requirements (EU Directive 2011/85), particularly for countries that adhere to the Fiscal Compact (the Treaty on Stability, Coordination and Governance) and with regard to the related national corrective mechanisms. Second, for euro area members, IFls undertake or endorse macroeconomic forecasts used in national budgets and stability or convergence programme updates ("two-pack" Regulation 473/2013).

There should be a legal obligation at the EU level to take into account national IFI assessments across a range of areas (EUIFI, 2021). The "obligation to take into account" the IFls' work more widely would codify existing practice where Commission teams regularly draw on IFIs, taking it a step further by making it a legal requirement. The obligation would not require the Commission and Council to follow the same approach or conclusions as the IFIs, but rather to consider the assessments of the IFIs. This could strengthen the legitimacy of EU-level decisions, where these already align with the IFIs' assessment, and provide some basis to take into account national specificities that are justified by the assessment of the national IFIs. This approach would reduce the risk that national IFIs are unduly undermined by contradictory assessments at the EU level.

There are a number of specific areas where IFIs are well placed to understand and assess specific national circumstances, as well as implications for the overall fiscal position (EUIFI, 2021):

- Measurement issues. This could include the identification of one-offs, estimation of potential output and structural balances and the measurement of discretionary revenue measures.

- Improving budgetary forecasting, where IFIs could have a greater role in the oversight of medium-term budgetary forecasts, extending their endorsement role from macroeconomic forecasts only.

- Compliance with rules that mirror requirements at the EU level. The current scope of assessment of compli- 
ance with some rules could only be extended across all the EU rules.

- Assessment at the national level, on a regular basis, of overall fiscal sustainability and the underlying fiscal position. This would help to ensure that formal compliance with the rules is supportive and sufficient for sound fiscal policy.

In all cases, assessment by the Commission and the Council would remain the formal legal benchmark. However, taking into account assessments by the IFIs could help to improve judgements at the EU level and to anchor them more firmly in the domestic institutional framework.

Situations may arise where Commission assessments differ from those of the national IFI, either on compliance with numerical benchmarks under the fiscal rules, the treatment of specific issues such as one-offs, or the overall fiscal position. The obligation for the EU institutions to take IFIs' assessments into account could help to narrow undue differences in interpretation of these assessments by providing some leeway for the Commission to consider national specificities. Providing clearer and more comprehensive common principles and guidance could further help to avoid these differences.

At the same time, it is vital that national IFIs retain their independence, including from judgements made at the EU level, so they are able to provide objective assessments of national circumstances. Many IFIs also have separate mandates connected to national fiscal frameworks that should not be compromised. National mandates of IFls are a key part of their legitimacy and ability to engage with national stakeholders. The obligation of EU institutions to take IFIs' assessments into account would - by leaving the ultimate decisions in EU hands - enhance the role of national IFIs without compromising it.

A key condition for IFls to play an enhanced role in the fiscal governance of the EU is to strengthen national independent fiscal institutions and their mandates. At present, there is a wide range of capacity across EU IFIs, reflecting differences in mandates and resources. The proposals in this paper would require IFI mandates to be extended in some cases, notably around monitoring compliance with the fiscal rules and in providing an overall assessment of the fiscal stance.

EUIFls (2021) identifies a number of areas where minimum standards set at the EU level for national institutions would help to strengthen many IFIs in their role at the EU level and domestically:
- A mandate to address government and parliament, and mandate to publicly disclose reports and recommendations. IFIs should be able to directly address national authorities and disclose reports and recommendations on their own initiative within their mandates.

- Adequate level of resources and management flexibility. IFI budgets should be protected from political interference, potentially through a multiyear budgetary appropriation that stretches beyond the national electoral cycle. IFls should also have adequate flexibility to manage their resources, to ensure their independence is preserved.

- Good and timely access to information. IFls should be able to obtain accurate information on demand from national statistical offices, national governments and the Commission without an undue delay and at no cost. Any restrictions on access to information should be clearly defined in law.

- Effective implementation of the "comply or explain" principle. This is a key instrument in the current IFI toolbox. The details on implementation of this principle should be included and clearly defined in national regulations.

- Sufficient safeguards against political pressures. It is essential that board members are selected under transparent procedures. The hiring process should be subject to strict rules on conflict of interest, and terms of board members should be independent of an electoral cycle.

\section{Improved statistics and data on public finances}

The setting and enforcement of fiscal rules and the assessment of fiscal sustainability should be supported by better statistics and information. Existing requirements to provide reliable statistical data on the general government fiscal position in a timely and comparable way and the independent oversight of macroeconomic forecasts are major achievements of the current EU fiscal governance.

The experience of national IFIs suggests a number of specific improvements to economic and budgetary information (EUIFIs, 2021):

- The requirement for member states to produce credible medium-term fiscal projections in all budgetary documents/Stability Programme Updates based on clear and credible policy assumptions covering at least four years ahead. This could include extending 
the requirement for projections to be endorsed by an independent body from macroeconomic to budgetary forecasts.

- Simplification, increased transparency and methodological improvements in the assessment of potential output. The existing potential output measures under the EU Commonly Agreed Methodology are procyclical (Darvas, 2019), especially at the end of the sample or of the forecast period. Consequently, output gaps are under-estimated (in absolute terms), particularly in some countries (Barnes and Casey, 2019). Any method to estimate the output gap or potential output is likely to face challenges, including the procyclical nature of many economic forecasts, and imply trade-offs. However, some methods perform better than others in terms of cyclicality and stability in real time.

- Medium-term debt sustainability analyses at the national level, either by governments subject to national IFI oversight or by national IFIs.

- Improved treatment of one-off measures and discretionary revenue measures in monitoring underlying fiscal positions. Net debt and net worth statistics should be published, as well as gross and net financing needs.

\section{The future of the EU fiscal governance}

This contribution, drawing on the experience of the national IFIs, lays out a three-pillar approach to strengthening the EU fiscal governance based on improving the numerical budget rules around a medium-term expenditure ceiling, strengthening the role and institutional framework of the IFIs, and improving statistics and data on fiscal policy.

Reform of the rules should be based on the experience both of what has worked and what has not worked. That is why this paper emphasises the criteria for effective rules, rather than any particular design choices. This calls for careful testing and evaluation of reforms before they are implemented. While there have been many challenges and weaknesses, the acceptance of a rules-based framework underpins most reform proposals. The creation of independent fiscal institutions in many EU countries has been a significant achievement and improved outcomes, although there is scope to use the IFIs more effectively in the EU context and to further strengthen IFIs in many countries. Improved statistics and data have also been a significant achievement of the EU governance framework. tions for national IFIs to develop by strengthening their mandates and institutional design, while assigning them a more explicit role at the EU level, could be a key part of this framework.

\section{References}

Barnes, S. and E. Casey (2019,17 June), Euro area budget rules on spending must avoid the pro-cyclicality trap, VoxEU.

Barnes, S. and I. Oliinyk (2021), The EU's economic governance review: Road-testing alternative fiscal rules?, CEPS Policy Insights, 2021-19.

Beetsma, R. and M. Larch (2018, 10 May), Risk reduction and risk sharing in EU fiscal policymaking: The role of better fiscal rules, VoxEU.

Beetsma, R., X. Debrun and R. Sloof (2017), The Political Economy of Fiscal Transparency and Independent Fiscal Councils, IMF Working Paper, WP/17/195.

Bénassy-Quéré, A., M. Brunnermeier, H. Enderlein, E. Farhi, M. Fratzscher, C. Fuest, P. Gourinchas, P. Martin, J. Pisani-Ferry, H. Rey, I. Schnabel, N. Véron, B. Weder di Mauro and J. Zettelmeyer $(2018,17$ January), How to reconcile risk sharing and market discipline in the euro area, VoxEU.

Blanchard, O., A. Leandro and J. Zettelmeyer (2020), Redesigning the EU Fiscal Rules: From Rules to Standards, 72nd Economic Policy Panel Meeting, Federal Ministry of Finance, Germany.

Capraru, S., G. Georgescu and N. Sprincean (2020), An Evaluation of IFIs Impact on EU Countries Budget Deficits, Romanian Fiscal Council Working Paper, 2.

Constancio, V. (2020), The Return of Fiscal Policy and the Euro Area Fiscal Rule, Comparative Economic Studies, 62(3), 358-372.

Darvas, Z., P. Martin and X. Ragot (2018), European fiscal rules require a major overhaul, Bruegel Policy Contribution, 18.

Darvas, Z. (2019, 1 October), Why structural balances should be scrapped from EU fiscal rules, Bruegel Blog.

Darvas, Z. and G. Wolff (2021, 9 September), A green fiscal pact: climate investment in times of budget consolidation, Bruegel Blog.

European Commission (2021), European Economic Forecast - Spring 2021, Institutional Paper, 149.

European Central Bank (2016), Public investment in Europe, ECB ECOnomic Bulletin, 2.

EU Network of Independent Fiscal Institutions (2016), Defining and enforcing minimum standards for IFIs.

EU Network of Independent Fiscal Institutions (2019), Network Statement on the Need to Reinforce and Protect EU IFIs.

EU Network of Independent Fiscal Institutions (2021), EU Fiscal and Economic Governance Review: A Contribution from the Network of Independent EU Fiscal Institutions.

Feld, L., C. Schmidt, I. Schnabel and V. Wieland (2018, 12 September), Refocusing the European fiscal framework, VoxEU.

Hagemann, R. (2011), How Can Fiscal Councils Strengthen Fiscal Performance, OECD Publishing, 2011(1), 1-24.

Martin, P., J. Pisany-Ferry and X. Ragot (2021, 26 May), A new template for the European fiscal framework, VoxEU. 